\title{
PENGARUH DISIPLIN KERJA TERHADAP KINERJA GURU SD NEGERI 2 SUMBEREJO BANDAR LAMPUNG
}

\author{
Sondri Riyadi ${ }^{(1)}$, Kuswarak $^{(2)}$, Maria Elina ${ }^{(3)}$ \\ Fakultas Ekonomi Universitas Sang Bumi Ruwa Jurai \\ Sondri_firdaus1@gmail.com,kuswarak@fe.saburai.ac.id,maria.elina@fe.saburai.ac.id
}

\begin{abstract}
Abstrak. Guru adalah suatu sebutan bagi jabatan, posisi, dan profesi bagi seorang yang mengabdikan dirinya dalam bidang pendidikan melalui proses edukatif secara terpola, formal, dan sistematis. Objek penelitian adalah guru SD Negeri 2 Sumberejo Bandar Lampung. Penelitian ini bertujuan untuk mengetahui apakah ada pengaruh disiplin kerja terhadap kinerja guru SD Negeri 2 Sumberejo Bandar Lampung. Sedangkan untuk penelitian ini adalah penelitian verifikatif deskriptif dengan menggunakan sampel sebanyak 31 responden yang dilakukan secara acak.Hasil penelitian menemukan bahwa ada pengaruh antara disiplin terhadap kinerja dengan nilai pengaruh pengaruh sebesar $40,5 \%$. Dalam penelitian ini juga ditemukan bahwa pengaruhnya adalah karena tingkat ketidakhadiran yang cukup tinggi di SD Negeri 2 Sumberejo Bandar Lampung.
\end{abstract}

Kata kunci: Disiplin kerja, kinerja, kontribusi, sumber daya manusia

\section{PENDAHULUAN}

Disiplin adalah fungsi operatif keenam dari Manajemen Sumber Daya Manusia. Disiplin merupakan fungsi operatif MSDM yang terpenting karena semakin baik disiplin karyawan atau guru, semakin tinggi prestasi kerja yang dapat dicapainya. Tanpa disiplin yang baik karyawan atau guru, sulit bagi organisasi perusahaan mencapai hasil kerja yang optimal. Disiplin yang baik mencermikan besarnya rasa tanggung jawab seseorang dengan tugas-tugas yang diberikan kepadanya. Hal ini mendorong gairah kerja, semangat kerja, dan terwujudnya tujuan organisasi, perusahaan, karyawan dan masyarakat.

Guru professional akan tercermin dalam penampilan pelaksanaan pengabdian tugas-tugas yang ditandai dengan keahlian baik dalam materi maupun metode. Keahlian yang dimiliki oleh guru professional adalah keahlian yang diperoleh melalui suatu proses pendidikan dan pelatihan yang diprogramkan secara khusus untuk itu. Keahlian tersebut mendapat pengakuan formal yang dinyatakan dalam bentuk sertifikasi, akreditasi, dan lisensi dari pihak yang berwenang (dalam hal ini pemerintah dan organisasi profesi). Dengan keahliannya itu seorang guru mampu menunjukkan otonominya, baik secara pribadi maupun sebagai pemangku profesinya.

Disamping dengan keahliannya, sosok professional guru ditunjukkan melalui tanggung jawabnya dalam melaksanakan seluruh pengabdiannya. Guru professional hendaknya mampu memikul dan melaksanakan tanggung jawab sebagai guru kepada peserta didik, orang tua, masyarakat, bangsa, Negara, dan agamanya. Guru professional mempunyai tanggung jawab pribadi, social, intelektual, moral dan spiritual. Tanggung jawab pribadi yang mandiri yang mampu memahami dirinya. Tanggung jawab social diwujudkan melalui kompetensi guru dalam memahami dirinya sebagai bagian yang tak terpisahkan dari lingkungan social serta memiliki kemampuan interaktif yang 
efektif. Tanggung jawab intelektual diwujudkan melalui penguasaan berbagai perangkat pengetahuan dan keterampilan yang diperlukan untuk menunjang tugastugasnya. Tanggung jawab spiritual dan moral yang diwujudkan melalui penampilan guru sebagai makhluk yang beragama yang perilakunya senantiasa tidak menyimpang dari norma-norma agama dan moral.

Terkait dengan norma maka salah satunya adalah norma yang terkait dengan ketentuan disiplin dalam melaksanakan tugas dan tanggung jawab profesinya. Kapan dia harus mulai masuk, dan keluar berapa lama melaksanakan tugas dan tanggung jawab profesinya. Kapan dia harus mulai masuk, dan keluar berapa lama melaksanakan proses belajar mengajar sebagainya, yang kesemuannya itu musti ditaati sebagai salah satu ciri dari guru yang professional yang memiliki sifat disiplin dalam melaksanakan tugas untuk mencapai prestasi kerja yang optimal. Disiplin merupakan salah satu "modal" kerja yang sangat berpengaruh terhadap kinerja guru. Pengalaman selama ini menunjukkan bahwa disiplin dimasyarakat khususnya di SD Negeri 2 Sumberejo Bandar Lampung belum efisien, dalam pelaksaannya tidak semua guru dalam menjalankan tugas bersikap disiplin sehingga hal ini berdampak pada stabilitas sekolah.

Sebagai pimpinan tertinggi di sekolah, Kepala Sekolah harus mampu mengelola waktu secara efisien, baik untuk tugas-tugas sendiri maupun untuk sekolah secara kesuluruhan. Sehingga kegiatan proses belajar mengajar dapat berjalan secara efektif dan efisien. Dalam rangka meningkatkan Disiplin Kerja Terhadap Kinerja Guru maka salah satu usaha yang dapat kita lakukan adalah dengan memahami dan sadar tugas dan tanggung jawab sebagai seorang guru serta meningkatnya proses perencanaan, pengawasan, dan pengendalian sehingga tercipta akan kedisiplinan di dalam diri masing-masing guru. Kedisiplinan merupakan fungsi manajemen sumber daya manusia terpenting dan kunci terwujudnya tujuan karena tanpa disiplin yang baik sulit terwujudnya tujuan yang maksimal (Hasibuan, 95: 2011). Tingkat kedisiplinan guru S D Negeri 2 Sumberejo Bandar Lampung dapat dilihat pada absensi guru

\section{KAJIAN TEORI}

\section{Pengertian Manajemen}

Manajemen adalah seni dalam mengatur sistem baik orang dan perangkat lain agar dapat berjalan dan bekerja sesuai dengan ketentuan dan tujuan entitas yang terdiri dari berbagai aktivitas

Manajemen merupakan proses yang khas yang terdiri dari tindakan-tindakan : perencanaan,

pengorganisasian, menggerkan dan pengawasan yang dialkukan untuk menentukan serta mencapai sasaran-sasaran yang telah ditetapkan melalui pemanfaatan sumber daya manusia serta sumber-sumber lain. (George R. Terry, 2010:48)

Manajemen adalah ilmu dan seni mengkoordinasikan serta mengawasi tenaga manusia dengan bantuan alat-alat untuk mencapai tujuan yang telah ditetapkan". (Oie Liang Gie, 2012:156)

Menurut Dr. Sp. Siagian Manajemen dapat di definisikan sebagai : "Kemampuan atau keterampilan untuk memperoleh suatu hasil dalam rangka pencapaian tujuan melalui orang lain".(Siagian, 2011:78)

\section{Pengertian Manajemen Sumber Daya Manusia}

Manajemen sumber daya manusia adalah suatu proses yang terdiri atas perencanaan, pengorganisasian, pemimpin dan pengendalian kegiatan-kegiatan yang berkaitan dengan analisis pekerjaan, 
evaluasi pekerjaan, pengadaan, pengembangan, kompensasi, promosi, dan pemutusan hubungan kerja guna mencapai tujuan yang ditetapkan (Panggabean, 2009:15).

Manajemen sumber daya manusia adalah potensi yang merupakan aset dan berfungsi sebagai modal (non material/non finansial) di dalam organisasi bisnis, yang dapat diwujudkan menjadi potensi nyata (real) secara fisik dan non fisik dalam mewujudkan eksistensi organisasi (Sulistiyani dan Rosidah, 2011:18).

\section{Pengertian Motivasi Kerja}

Menurut Hasibuan Malayu S.P dalam Sunyoto Danang (2012:191) motivasi adalah suatu perangsang keinginan daya gerak kemauan bekerja seseorang, setiap motif mempunyai tujuan tertentu yang ingin dicapai. Sedangkan Asa'ad dalam Pasolog, Harbani (2010:140) motivasi adalah sesuatu yang menimbulkan semangat atau dorongan kerja.

Berdasarkan pendapat para ahli diatas, maka dapat disimpulkan bahwa motivasi merupakan dorongan yang dapat membangkitkan kemauan kerja untuk memulai melaksanakan pekerjaan sesuai tugas dan tanggung jawabnya. Tujuan Motivasi menurut Sunyoto Danang (2012:198) tujuan motivasi antara lain :

1. Mendorong gairah dan semangat kerja karyawan

2. Meningkatkan moral dan kepuasan kerja karyawan

3. Meningkatkan produktivitas kerja karyawan

4. Mempertahankan loyalitas dan kestabilan karyawan perusahaan

5. Menciptakan suasana dan hubungan kerja yang baik.

6. Meningkatkan kreativitas dan partisipasi karyawan.

\section{Pengertian Kinerja}

Menurut A. Tabrani Rusyan dkk, (2000:17), Kinerja guru adalah

melaksanakan proses pembelajaran baik dilakukan di dalam kelas maupun di luar kelas di samping mengerjakan kegiatankegiatan lainnya, seperti mengerjakan administrasi sekolah dan administrasi pembelajaran, melaksanakan bimbingan dan layanan pada para siswa, serta melaksanakan penilaian.

Menurut Mangkunegara kinerja adalah Hasil kerja secara kualitas dan kuantitas yang dicapai oleh seorang pegawai dalam melaksanakan tugasnya sesuai dengan tanggung jawab yang diberikan kepadanya (Mangkunegara, 2011:45)

Sedangkan menurut Nawawi Hadari (2013:65), yang dimaksud dengan kinerja adalah Hasil dari pelaksanaan suatu pekerjaan, baik yang bersifat fisik/mental maupun non fisik/non mental. Menurut Prawiro Suntor (2011:157) bahwa pengertian kinerja adalah hasil kerja yang dapat dicapai seseorang ataupun sekelompok orang dalam suatu organisasi dalam rangka mencapai tujuan organisasi dalam waktu tertentu.

\section{METODE PENELITIAN}

\section{Objek Penelitian}

Dalam penelitian ini yang menjadi objek penelitian adalah guru di SD Negeri 2 Sumberejo Bandar Lampung.

\section{Metode dan Teknik Pengumpulan Data}

Data yang digunakan pada penelitian ini adalah :

a) Data Primer

Merupakan data yang dikumpulkan dan diolah sendiri oleh peneliti langsung dari objek penelitian.

b) Data Sekunder 
Merupakan data yang diperoleh peneliti dalam bentuk yang sudah jadi, sudah dikumpulkan dan diolah oleh pihak lain.

Teknik Pengumpulan Data

- Observasi

Metode observasi atau pengamatan adalah kegiatan keseharian manusia dengan menggunakan panca indera mata dan dibantu dengan panca indera lainnya (Bungin 2011:142)

- Kuesioner

Pengumpulan data dengan cara memberikan daftar isian responden secara langsung.

\section{Sampel dan Populasi}

Populasi dalam penelitian ini adalah seluruh guru yang ada di SD Negeri 2 Sumberejo. Populasi 35 orang, dari 35 orang diambil 31 orang (Kepala sekolah, operator TU, satpam dan penjaga sekolah) tidak dimasukkan dalam penelitian ini.

\section{Metode Analisis Data}

a) Analisis Kualitatif

Analisis kualitatif adalah riset yang cara pengolahan datanya tidak dikuantifikasi atau tidak dihitung dan tidak menggunakan analisis matematis. Analisis kualitatif menurut Sugiyono (2012:13) adalah metode penelitian yang berlandaskan pada filsafat positifisme, digunakan untuk meneliti pada kondisi obyek yang alamiah, (sebagai lawannya adalah eksperimen) dimana peneliti sebagai instrument kunci, pengambilan sampel sumber data dilakukan secara (gabungan), analisis data bersifat induktif/ kualitatif, dan hasil penelitian kualitatif lebih menekankan makna dari pada generalisasi.

b) Analisis Kuantitatif, Analisis dengan menggunakan metode kuantitatif dilakukan dengan melakukan pengolahan dari kuisioner yang ada dengan menggunakan analisis regresi sederhana dan korelasi untuk mengetahui seberapa erat hubungan antara variabel $\mathrm{Y}$ (kinerja) dengan variabel $\mathrm{X}$ (disiplin). Analisis kuantitatif adalah analisis dengan menggunakan pendekatan atau rumus statistik.

c)

Pada penelitian ini analisis kuantitatif yang digunakan adalah analisis regresi sederhana. Setelah dilakukan pengintervalan data hasil kuisioner, maka analisis regresi dapat dilakukan dengan menentukan persamaan sebagai berikut:

$$
Y=\alpha+b x+e
$$

Keterangan :

$\mathrm{Y}=$ Kinerja Guru

$\alpha=$ Konstanta

$b=$ Koefisien regresi variabel bebas

$x=$ Disiplin Kerja

$e=$ Standar Error

\section{Uji F}

Uji ini digunakan untuk mengetahui apakah variabel independen yaitu Disiplin Kerja (X) berpengaruh secara signifikan terhadap variabel dependen yaitu Kinerja (Y) pada tingkat kepercayaan $95 \%$ atau $\alpha=$ $5 \%$.

Hipotesis statistiknya yaitu:

Ho $=$ Variabel $\mathrm{X}$ tidak ada pengaruh signifikan secara simultan terhadap variabel Y.

$\mathrm{Ha}=$ Variabel $\mathrm{X}$ berpengaruh signifikan secara simultan terhadap variabel $\mathrm{Y}$.

Dengan kriteria:

a. Ha diterima jika $\mathrm{F}_{\text {hitung }}>\mathrm{F}_{\text {tabel }}$

b. Ha ditolak jika $F_{\text {hitung }}<\mathrm{F}_{\text {tabel }}$

\section{Uji t}


Uji t digunakan untuk mengetahui pengaruh antara masing-masing variabel bebas terhadap variabel terikat secara parsial dengan menggunakan uji $\mathrm{t}$ pada tingkat kepercayaan $95 \%$ atau dengan nilai $\alpha=5 \%$, serta menggunakan nilai derajat kebebasan (Degree of Freedom) (Ghozali, 2012:93).

Pernyataan hipotesis :

Ho : Secara parsial tidak ada pengaruh signifikan antara variabel $\mathrm{X}$ terhadap variabel Y.

$\mathrm{Ha}$ : Secara parsial terdapat pengaruh signifikan antara variabel $\mathrm{X}$ terhadap variabel Y.

Dengan kriteria :

Ho diterima dan Ha ditolak bila $t_{\text {hitung }}<\mathrm{t}_{\text {tabel }}$ Ha diterima dan Ho ditolak bila $t_{\text {hitung }}>t_{\text {tabel }}$

\section{HASIL DAN PEMBAHASAN}

\section{Analisis Kualitatif}

Berikut adalah hasil rincian jawaban responden terhadap pernyataan dalam kuesioner berdasarkan pengumpulan data terkait pengaruh Disiplin Kerja Terhadap Kinerja Guru SD Negeri 2 Sumberejo di Bandar Lampung.

Tabel Total Skor Indikator Variabel X

\begin{tabular}{|c|l|c|}
\hline No & \multicolumn{1}{|c|}{ Indikator } & Total Skor \\
\hline 1 & $\begin{array}{l}\text { Pekerjaan yang deberikan } \\
\text { dapat selesai tepat waktu }\end{array}$ & 121 \\
\hline 2 & $\begin{array}{l}\text { Dalam bekerja selalu } \\
\text { berpakaian rapih }\end{array}$ & 116 \\
\hline 3 & $\begin{array}{l}\text { Materi yang disampaikan } \\
\text { oleh anda jelas dan } \\
\text { dimengerti oleh orang lain }\end{array}$ & 119 \\
\hline 5 & $\begin{array}{l}\text { Sangsi dan peringatan } \\
\text { diberikan kepada murid } \\
\text { yang nakal }\end{array}$ & $\begin{array}{l}\text { Latihan soal dan PR diberikan } \\
\text { kepada siswa sesuai dengan } \\
\text { target }\end{array}$ \\
\hline 6 & $\begin{array}{l}\text { Pemberian materi yang } \\
\text { diberikan sesuai yang } \\
\text { ditetapkan Dinas Pendidikan }\end{array}$ \\
\hline
\end{tabular}

Selalu mengoptimalkan waktu pada proses belajar mengajar

101

Hal ini menunjukkan bahwa sebagian besar guru dapat menyelesaikan perkerjaannya sesuai waktu yang ditentukan. Para guru merasa dengan menyelsaikan tugas sesuai waktu berarti kinerja mereka sudah cukup baik.

\section{Analisis Kuantitatif}

Untuk mengetahui pengaruh Disiplin Kerja (X) Terhadap Kinerja Guru (Y) SD Negeri 2 Sumberejo di Bandar Lampung, maka digunakan pendekatan alat analisis regresi linier sederhana. Pengujian dilakukan dengan $\mathrm{n}$ sebesar 31 dengan tingkat keyakinan sebesar $95 \%$ atau $\alpha=$ 0,05 .

Berikut adalah hasil perhitungan yang dilakukan dengan SPSS 20.0 :

Tabel Hasil Perhitungan Regresi

\begin{tabular}{|c|c|c|c|c|c|c|}
\hline $\begin{array}{l}\text { Vari } \\
\text { abel }\end{array}$ & $\begin{array}{c}\text { Koefis } \\
\text { ien }\end{array}$ & $\mathbf{F}$ & $\mathbf{t}$ & $\mathbf{R}$ & $\mathbf{R}^{2}$ & $\begin{array}{l}\text { Dur } \\
\text { bin- } \\
\text { Wat } \\
\text { son }\end{array}$ \\
\hline $\begin{array}{c}\text { Kons } \\
\text { tanta } \\
\text { Disip } \\
\text { lin } \\
\end{array}$ & $\begin{array}{c}19,694 \\
0,692\end{array}$ & 19,699 & $\begin{array}{l}4,710 \\
4,438\end{array}$ & 0,636 & $\begin{array}{c}0,40 \\
5\end{array}$ & $\begin{array}{c}1,82 \\
1\end{array}$ \\
\hline
\end{tabular}

Sumber: Data yang diolah (2017)

Rumus regresi linier sederhana :

$$
Y=a+\beta x+e
$$

Berdasarkan Tabel maka diperoleh persamaan rumus regresi linier sederhana sebagai berikut :

$$
Y=19,694+0,692 X+e
$$

Koefisien regresi variabel Disiplin Kerja (X) sebesar 0,636. Hal ini berarti, nilai koefisien bernilai positif dan mengindikasikan bahwa terjadi hubungan 
yang positif antara variabel disiplin dengan variabel kinerja guru. Artinya jika disiplin kerja naik maka kinerja naik atau sebaliknya.

\section{Hasil Uji F}

Uji ini digunakan untuk mengetahui apakah variabel indepen den yaitu Disiplin Kerja (X) berpengaruh secara signifikan terhadap variabel dependen yaitu Kinerja (Y) pada tingkat kepercayaan $95 \%$ atau $\alpha=$ $5 \%$.

Berdasarkan tabel presentase distribusi $\mathrm{F}$ dengan nilai significance error $=0,05$ maka diperoleh nilai $\mathrm{F}$ Tabel $=4,18$ Hipotesis statistiknya yaitu:

Ho $=$ Variabel $\mathrm{X}$ tidak ada pengaruh signifikan secara simultan terhadap variabel Y.

$\mathrm{Ha}=$ Variabel $\mathrm{X}$ berpengaruh signifikan secara simultan terhadap variabel $\mathrm{Y}$.

Dengan kriteria:

a. Ha diterima jika $F_{\text {hitung }}>F_{\text {tabel }}$

b. Ha ditolak jika $F_{\text {hitung }}<\mathrm{F}_{\text {tabel }}$

Berdasarkan tabel analisis kuantitatif hasil $\mathrm{F}$ hitung adalah 19,699 > F tabel yaitu 4,18. Hal ini mengindikasikan bahwa $\mathrm{Ha}$ diterima dan Ho ditolak, yang berarti terdapat pengaruh dignifikan secara simultan antara variabel $\mathrm{X}$ terhadap $\mathrm{Y}$.

\section{Hasil Uji t}

Uji t digunakan untuk mengetahui pengaruh antara masing-masing variabel bebas terhadap variabel terikat secara parsial dengan menggunakan uji $\mathrm{t}$ pada tingkat kepercayaan $95 \%$ atau dengan nilai $\alpha=5 \%$, serta menggunakan nilai derajat kebebasan (Degree of Freedom) (Ghozali, 2012:126).

Berdasarkan tabel presentase distribusi $\mathrm{t}$ dengan nilai probabilita $=0,05$ maka diperoleh nilai $\mathrm{t}_{\text {Tabel }}=1,697$
Pernyataan hipotesis :

Ho : Secara parsial tidak ada pengaruh signifikan antara variabel $\mathrm{X}$ terhadap variabel Y.

$\mathrm{Ha}$ : Secara parsial terdapat pengaruh signifikan antara variabel $\mathrm{X}$ terhadap variabel Y.

Dengan kriteria :

Ho diterima dan Ha ditolak bila $\mathrm{t}_{\text {hitung }}<\mathrm{t}_{\text {tabel }}$ Ha diterima dan Ho ditolak bila $t_{\text {hitung }}>t_{\text {tabel }}$

Berdasarkan tabel analisis kuantitatif hasil $\mathrm{t}$ hitung adalah 4,438>t tabel yaitu 1,697. Hal ini mengindikasikan bahwa Ha diterima dan Ho ditolak, yang berarti terdapat pengaruh dignifikan secara parsial antara variabel X terhadap Y

\section{KESIMPULAN DAN SARAN}

\section{Kesimpulan}

Berdasarkan hasil penelitian dan pembahasan yang sudah dilakukan maka dapat disimpulkan sebagai berikut :

1. Berdasarkan analisis serta pembahasan maka ditarik kesimpulan bahwa disiplin berpengaruh terhadap kinerja guru pada SD Negeri 2 Sumberejo Bandar Lampung.

2. Hasil analisis kualitatif mengenai disiplin kerja, secara umum guru di SD Negeri 2 Sumberejo Bandar Lampung telah mampu melaksanakan tugasnya dengan baik. Akan tetapi dalam hal mengoptimalkan waktu dalam proses belajar mengajar dirasa masih kurang dilihat dari total skor pada indikator tersebut.

3. Hasil pengujian untuk mengetahui pengaruh disiplin kerja terhadap kinerja guru SD Negeri 2 Sumberejo Bandar Lampung mengunakan pendekatan analisi regresi linear memperoleh nilai $\mathrm{R}^{2}=0,405$. Hal ini berarti sumbangan 
variabel $X$ (Disiplin Kerja) berperan dalam mempengaruhi variabel $Y$ (Kinerja) sebesar 40,5\%.

\section{Saran}

Berdasarkan Kesimpulan diatas penulis mengemukakan saran sebagai berikut:

1. Kedisiplinan guru dalam bekerja secara umum berjalan dengan baik akan tetapi lebih baik agar ditingkatkan lagi, dengan cara menerapkan sanksi-sanksi baik administratif seperti yang tertuang dalam PP Nomor 53 Tahun 2010:

a. Penundaan kenaikan gaji berkala selama 1 tahun

b. Penundaan penerimaan tunjangan

Maupun sanksi non administratif seperti:

a. Penundaan kenaikan pangkat selama 1 tahun

b. Pemindahan dalam rangka penurunan jabatan setingkat lebih rendah.

Sehingga dengan disiplin yang baik guru sadar dan bersedia mengerjakan semua tugasnya dengan baik.

2. Dalam menyikapi tingkat absensi yang tinggi Kepala Sekolah diharapkan menerapkan sistem dengan Finger Print sehingga guru tidak lagi membolos disaat jam kerja guru.

3. Kepala Sekolah disarankan melakukan pengawasan terhadap guru di kelas dan sekitar sekolah dengan memasang CCTV (Closed Circuit Television) untuk mengawasi gerak-gerik guru agar mereka tetap menjaga kedisiplinannya dalam mengajar dan meningkatkan kinerja guru sehingga para guru bisa menjadi contoh guru yang melakukan pengajaran dengan baik.

4. Peningkatan kinerja guru juga bisa dilakukan dengan cara menggali informasi dari murid melalui pengisian angket dan kotak saran mengenai kinerja guru dan proses pembelajaran oleh murid.

\section{DAFTAR PUSTAKA}

Ambar, Teguh Sulistiyani dan Rosidah. 2011. Manajemen Sumber Daya Manusia. Yogyakarta: Graha Ilmu..

Feriana. 2013. Pengaruh Kepemimpinan dan Disiplin Kerja Terhadap Kinerja karyawan Pada PT Nakau di Lampung Utara. (Skripsi). Bandar Lampung: Fakultas Ekonomi Manajemen, Universitas Saburai.

Ghozali, Imam. 2012. Aplikasi Analisis Multivariate dengan SPSS. Semarang: BP UNDIP.

Hasibuan, Malayu S.P. 2011. Manajemen Sumber Daya Manusia (Edisi Revisi). Cetakan ke-12. Jakarta: Bumi Aksara.

Mangkunegara, A. A. Anwar Prabu. 2011. Manajemen Sumber Daya Manusia Perusahaan. Bandung: Remaja Rosda Karya.

Nawawi, Hadari. 2013. Evaluasi dan Manajemen Kinerja di Lingkungan Perusahaan dan Industri. Yogyakarta: Gadjah Mada Univercity Press.

Nur' Aeni, dkk. 2016. Buku Pedoman Penyusunan, Penulisan Skripsi, Ujian Skripsi dan Komprehensif. Bandar Lampung: Universitas Saburai.

Robbins, Stephen P. dan Judge, Timothy A. 2008. Perilaku Organisasi, Buku 2. Jakarta: Salemba Empat. 
Tintami, Lila., Pradhanawati, Ari., dan Susanto, Hari. 2012. "Pengaruh Budaya Organisasi Dan Gaya Kepemimpinan Transformasional Terhadap Kinerja Karyawan Melalui Disiplin Kerja Pada Karyawan Harian SKT Megawon II PT. Djarum Kudus". e-Journal, Vol. 2, No.1: 1-8.

Mathis, Robert. L \& Jackson. H. 2006. Manajemen Sumber Daya Manusia, Edisi 10. Jakarta: Salemba Empat

Sedarmayanti. 2011. Manajemen Sumber Daya Manusia dan Manajemen PNS, Cetakan Kelima. Bandung: PT. Refika Aditama.

Siagian, Sondang P. 2001. Manajemen Sumber Daya Manusi. Jakarta: Gunung Agung.

Handoko, T. Hani. 1999. Manajemen Edisi kedua. Yogyakarta: BPFE. 